\title{
Mutans Streptococci counts from saliva and its protein profile in early childhood caries
}

\author{
ENDANG W. BACHTIAR ${ }^{1,2, *}$, FERRY P. GULTOM $^{1}$, ATIKA RAHMASARI $^{1}$, BOY M. BACHTIAR $^{1,2}$
}

\author{
${ }^{1}$ Faculty of Dentistry, Department of Oral Biology, Universitas Indonesia, Jakarta, Indonesia \\ ${ }^{2}$ Oral Sciences Research Center, Faculty of Dentistry, Universitas Indonesia, Jakarta, Indonesia \\ ${ }^{*}$ Corresponding author: Endang W. Bachtiar; Faculty of Dentistry, Department of Oral Biology, Oral Sciences Research Center, Universitas \\ Indonesia, Salemba Raya 4, Jakarta 10430, Indonesia; Phone: +62 81 3195 71866; Fax: +62 213193 1412; E-mail: endangwiniati08@gmail.com
}

(Received: April 25, 2018; Revised manuscript received: June 20, 2018; Accepted: July 18, 2018)

\begin{abstract}
Aim: This study aims to analyze the number Mutans Streptococci (MS) and its protein profile from the saliva of early childhood caries (ECC) and caries-free subjects. Methods: MS counts were cultured from saliva samples, and the protein profile of MS was determined from ECC and caries-free subjects. The number of colonies were counted, and the protein bands with the molecular weight of $13,29,39,41.3,74$, and $95 \mathrm{kDa}$ were determined by sodium dodecyl sulfate polyacrylamide gel electrophoresis method. Results: We found that the number of colonies from saliva of ECC patients was higher than those caries-free $(22.20 \times 106 \mathrm{CFU} / \mathrm{ml}$ vs. $19.16 \times 106 \mathrm{CFU} / \mathrm{ml}, p<0.05)$. There are higher expression frequencies in protein 29,39,41.3, and $74 \mathrm{kDa}$ of MS in ECC than caries-free subjects. Conclusions: There is the higher number of MS colonies and difference of MS protein profile isolated from saliva among children with ECC and caries-free counterparts.
\end{abstract}

Keywords: Mutans Streptococci, protein profile, saliva, early childhood caries, dmft

\section{Introduction}

Early childhood caries (ECC) is defined as a condition of one or more of decayed, missing, and filling in teeth (dmft) of children aging less than 71 months or even younger [1]. Prevalence and severity of ECC is still high in some countries. According to Indonesian Basic Health Survey (RISKESDAS) in 2013, national $\mathrm{dmft}$ index in Indonesia reaches 4, 6 [2]. In 1988, the prevalence of ECC at preschool age in DKI Jakarta and its surrounding area was $85.17 \%$. The definition of ECC is the presence of one or more decayed (non-cavitated or cavitated lesions), missing (due to caries), or filled tooth surfaces in any primary tooth in a child under the age of 6 years [3]. This condition will lead to a decrease in children's health quality, where ECC can decrease the chewing ability of the children, so that it can interfere in growth and development of children $[4,5]$.

ECC is a multifactorial disease that occurs due to host, environment, and microorganism as the etiology factors $[5,6]$. Mutans Streptococci (MS) is the main microorganism that causes ECC. In the past decade, several researches conducted in the relationship between the occurrence of caries and the presence of salivary MS [7]. Saliva may transmit the bacteria and plays a role as a reservoir for the colonization of the bacteria. If the cariogenic bacteria predominate in saliva and plaque, it will increase the acids, which are produced by them through the fermentation process of carbohydrate. This will also increase the colony of the bacteria and start creating virulence biofilm on tooth surface by quorumsensing mechanism [8].

One of the main factors of MS virulence is the ability to produce glucan synthesized by glusyltransferase, which mediated microorganism attachment to the tooth surface along with other protein, such as I/II antigen 185, PAc 190, GbpA 74, GbpB 41,3 kDa, etc. The proteins affect biofilm formation and increase caries activity in children (ECC) [9]. Hence, we are interested to observe the difference of MS amount and protein profile isolated from saliva in ECC subjects compared to caries-free children.

This is an open-access article distributed under the terms of the Creative Commons Attribution-NonCommercial 4.0 International License, which permits unrestricted use, distribution, and reproduction in any medium for non-commercial purposes, provided the original author and source are credited, a link to the CC License is provided, and changes - if any - are indicated. 


\section{Materials and Methods}

This study obtained ethical approval from ethical research committee of Faculty of Dentistry, Universitas Indonesia (no.: 24/Ethical Approval/FKGUI/V/2017). An examination was carried out by measuring the number of dmft teeth of children.

MS was isolated from saliva sample on the floor of the mouth, mandibular buccal, and labial vestibular using transfer pipette. The saliva samples were collected in $1.5 \mathrm{ml}$ microcentrifuge tube, which contained phosphate-buffered saline and $0.01 \mathrm{mM}$ phenylmethylsulfonyl fluoride. The bacteria were collected from 16 children of ECC and 16 caries-free children, aged below 71 months in Al-Mutazam Kindergarten, Depok, West Java. Samples were cultured with trypticase soy agar and incubated in an anaerobic condition at $37^{\circ} \mathrm{C}$ for $72 \mathrm{~h}$. Then, the bacterial culture colonies were counted prior subculture in tryptic soy broth for further incubation in an anaerobic condition in $370{ }^{\circ} \mathrm{C}$ for $72 \mathrm{~h}$. Preparation of MS protein was carried out by bacterial cell lysate method [9]. The protein was added with $0,3 \mathrm{ml}$ Tris, EDTA and $\mathrm{NaCl}$ buffer and 0.065 sodium dodecyl sulfate (SDS; $10 \%)$. It was incubated for $10 \mathrm{~min}$ at $37^{\circ} \mathrm{C}$. The protein concentration was measured by Bradford protein assay methods.

\section{SDS polyacrylamide gel electrophoresis methods}

Resolving gel and stacking gel were made until wells are formed. Samples and protein marker were run in each well to electrophoresis procedure. Electrophoresis tank was connected to the power source and had been set about $150 \mathrm{~V}, 80 \mathrm{~mA}$ for $70 \mathrm{~min}$ [10].

\section{Results}

MS count

The number of MS from the saliva of ECC patients was higher than caries-free children; there were $22.20 \times 106$ and $19.16 \times 106 \mathrm{CFU} / \mathrm{ml}$, respectively (Fig. 1). We also analyzed the dmft score of MS count. The data show that the severity of dmft correlates with the number of MS in which the higher dmft value is in line with MS amount in the saliva $(p<0.05)$ (Fig. 2).

\section{Protein profile of MS in ECC and caries-free subjects}

Figure 3 shows that the expression of the protein with molecular weight $29 \mathrm{kDa}$ is found higher in ECC subjects ( $100 \%)$ than caries-free $(56.25 \%)$; the $39-\mathrm{kDa}$ protein is also found higher in ECC subjects $(93.7 \%)$ than cariesfree subjects $(31.25 \%)$. The appearance of protein that

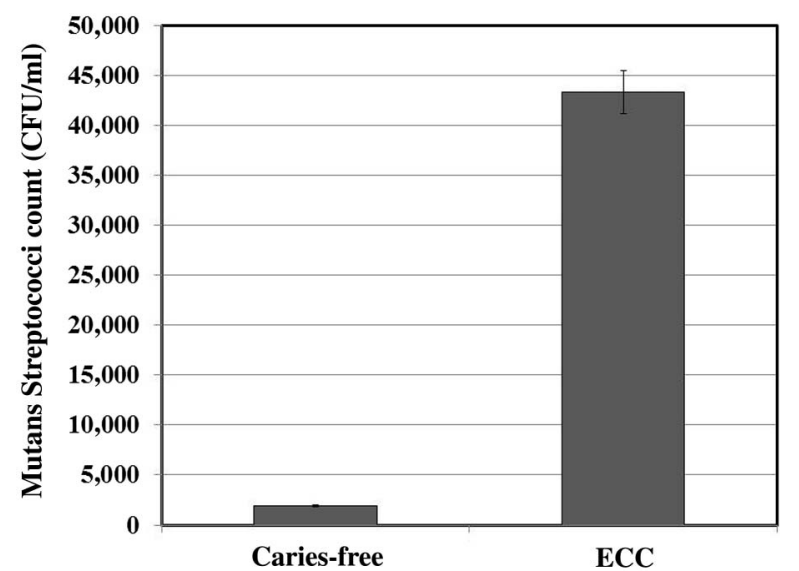

Fig. 1. The quantity of Mutans Streptococci in saliva of ECC patients and caries-free children

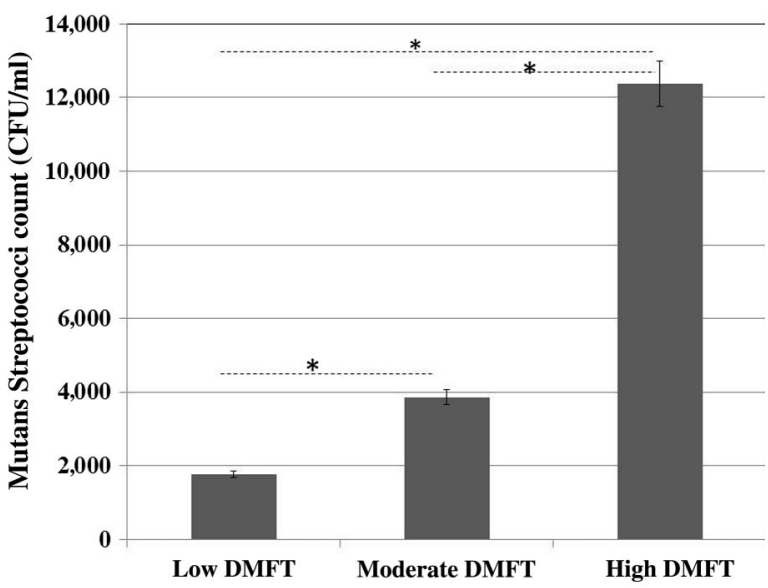

Fig. 2. Distribution of the quantity of Mutans Streptococci in saliva of low, moderate, and high dmft of patients. ${ }^{*} p<0.05$

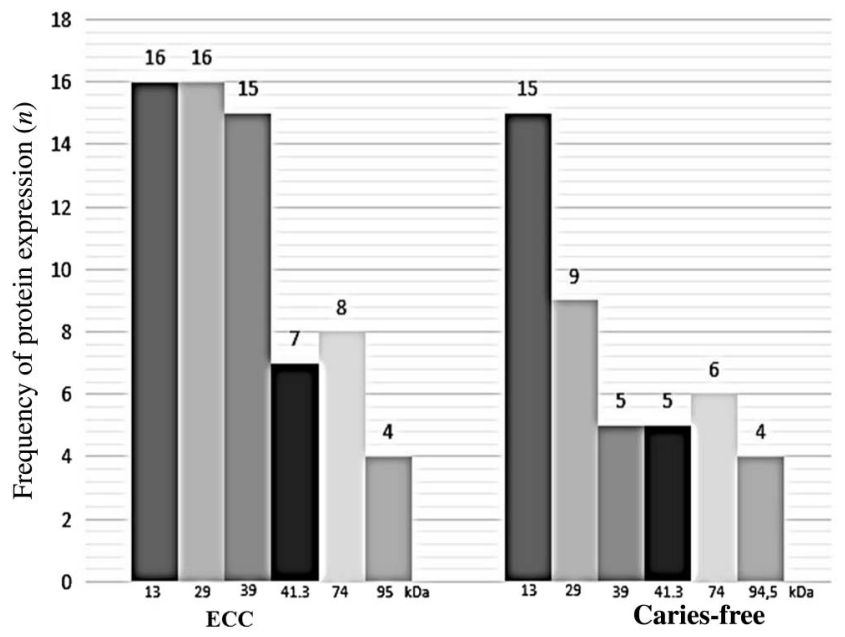

Fig. 3. The expression of protein with molecular weight of Mutans Streptococci in ECC and caries-free subjects

has molecular weight $41.3 \mathrm{kDa}$ found higher in ECC subjects $(43.75 \%)$ than caries-free subjects $(31.25 \%)$. The $74-\mathrm{kDa}$ protein band appears higher in ECC subjects 
$(50 \%)$ than caries-free subjects $(37.5 \%)$. Finally, the protein with molecular weight $95 \mathrm{kDa}$ appears at same frequency between ECC and caries-free subjects (25\%). There was the difference of MS protein profile, which was isolated from saliva in ECC and caries-free subjects.

\section{Discussion}

A large number of studies previously have established a positive correlation between MS and ECC [11, 12]. The results of this study also confirmed that $\mathrm{MS}$ was associated with ECC as indicated by the number of colonies (ECC children had more MS colonies). A positive correlation was also found between severity of ECC as measured by the dmft index and high levels of MS counts, indicating that as the number of colonies increased, the number of teeth and surfaces affected by caries also increased.

Protein with molecular weight $13 \mathrm{kDa}$ was suspected as antigen $\mathrm{D}, 29 \mathrm{kDa}$ as antigen $\mathrm{A}, 39 \mathrm{kDa}$ as antigen III (AgIII), $41.3 \mathrm{kDa}$ as $\mathrm{GbpB}, 74 \mathrm{kDa}$ as $\mathrm{GbpA}$, and $94.5 \mathrm{kDa}$ as dextranase (DexA) [13-18].

The frequency of $13 \mathrm{kDa}$ antigen $\mathrm{D}$, collected from saliva, that is detected in this research is not much different even though higher in ECC than caries-free subjects. According to Russel in 1993, this protein had been identified before as a protein with a low molecular mass. It was explained more by Roman et al. in 2013 that those proteins with a low molecular mass responded to enzymes, which involve in amino acid production. This antigen will interact with another protein that resides in the human body for which it will take part in the early process of active caries. Thus, it is assumed that protein whose molecule weighs $13 \mathrm{kDa}$ presents both in ECC and caries-free subjects $[13,19]$.

Another protein, which has molecular weight $29 \mathrm{kDa}$, suspected as an antigen A [15]. This antigen does not involve in dextran bond, which may take part in early bacterial colonization [19]. Another research reported that even though the specific role of antigen A remains unclear, individuals who received this antigen immunization may be protected from the caries process [20]. It happened because antigen $\mathrm{A}$ induces $\operatorname{IgA}$ antibody that may disrupt the adherence and bacterial colonization, which initiates the caries process $[13,15]$. But the result in this research reports that the expression in ECC is higher than caries-free subjects; this may be caused by the caries risk factor more dominant like salivary flow rate or buffer capacity than the immunologic factor, such as level of IgA antibody [13].

Protein with molecular weight $39 \mathrm{kDa}$ is suspected as AgIII, whose frequency has been detected more on ECC subject. This protein found on the whole surface of the cell. The function of this protein remains unclear [13]. This protein is one of cell surface antigens on MS, which is immunogenic for some population that induced $\mathrm{IgG}$ antibody in caries-active groups or with the history of caries. On the other hand, based on some literature and research, IgG also found less sensitive in the role of protection to caries compare with $\operatorname{IgA}$ [15].

GbpB protein, which molecule protein weight assumed is $41.3 \mathrm{kDa}$, isolated from saliva and the result of this research is higher in ECC subject. According to Mattos-Graner et al. in 2001, GbpB has a positive correlation to biofilm formation. GbpB also may have a role in cell walls formation, which influences their growth and lives $[16,21]$. In summary, if there is no GbpB presence in the cell of MS, these bacteria cannot grow and survive. The caries-free subject may be as the result of less GbpB expression in MS, followed by the disruption of the bacterial growth. Thus, it could be concluded that GbpB maintains the integrity of the bacteria cell formation and leads to biofilm increase [16].

Protein with molecule weight $74 \mathrm{kDa}$ was suspected as GbpA protein. As functionally, GbpA contribute to adherence and cohesivity of MS. Hazlett et al. reported that GbpA protein has a hypercariogenic affinity resulted from plaque structure changes raise acid production on enamel and barrier made between tooth surfaces and saliva. A hypercariogenic affinity leads to demineralization and also decreases saliva buffering capacity. GbpA protein also found to enhance bacterial adhesion to the tooth enamel via sucrose [22]. Therefore, this molecular weight is suspected that it directly contributes to form caries lesion.

Protein with molecular weight $94.5 \mathrm{kDa}$ has the same frequency of expression both in ECC and caries-free subjects in this research, suspected as DexA [18]. The virulence properties of this protein remain unclear. From several studies, DexA not only able to hydrolyze water insoluble glucan, which reduces the adherence of MS to enamel surfaces, but also inhibits biofilm forming on tooth surface [23]. Other research also reported that DexA together with glucanohydrolase would impact in reducing the total glucans [24-26].

\section{Conclusion}

The number of MS and the expression of some protein bands were higher in ECC subjects compared to cariesfree subjects.

\section{$* * *$}

Funding sources: This project was supported by the grant from Universities Indonesia (PITTA) 2018.

Authors' contribution: EWB designed the study and wrote the first draft of the manuscript. BBM wrote the protocol. AR and FPG carried out sample collection and laboratory work. All authors read and approved the final version of the manuscript.

Conflict of interest: The authors declared no competing interests exist. 


\section{References}

1. Hajishengallis E, Parsaei $\mathrm{Y}$, Klein MI, Koo H: Advances in the microbial etiology and pathogenesis of early childhood caries. Mol Oral Microbiol 32, 24-34 (2017)

2. Badan Penelitian dan Pengembangan Kesehatan Kementerian Kesehatan RI (2013): Ris Kesehat Dasar, Indonesian Ministry of Health, Indonesia, pp. $\mathrm{x}-\mathrm{xi}$

3. Drury TF, Horowitz AM, Ismail AI, Maertens MP, Rozier RG, Selwitz RH: Diagnosing and reporting early childhood caries for research purposes. J Public Health Dent 59, 192-197 (1999)

4. Begzati A, Berisha M, Mrasori S, Xhemajli B, Prokshi R, Haliti F (2015): Early childhood caries - Etiology, clinical consequences and prevention. In: Emerging trends in oral health sciences and dentistry [Internet], ed Singh Virdi M, InTech, Rijeka, p. 852. Retrieved from https://www.intechopen.com/books/emergingtrends-in-oral-health-sciences-and-dentistry/early-childhood-cariesecc-etiology-clinical-consequences-and-prevention

5. Sun X, Huang X, Tan X, Si Y, Wang X, Chen F, Zheng S: Salivary peptidome profiling for diagnosis of severe early childhood caries. J Transl Med 14, 240 (2016)

6. Mcdonald RE, Avery DR, Dean JA (2004): Dentistry for the child and adolescent. In: Early Childhood Caries, Severe Early Childhood Caries, Nursing Caries, Baby Bottle Tooth Decay (8th ed), eds Rudolph P, Pendill J, Mosby, St. Louis, pp. 209-212

7. Kawashita Y, Kitamura M, Saito T: Early childhood caries. Int J Dent 2011, 1-7 (2011)

8. Guo L, Shi W: Salivary biomarkers for caries risk assessment. Natl Inst Health 41, 107-118 (2013)

9. Loesche WJ: Role of Streptococcus mutans in human dental decay. Microbiol Rev 50, 353-380 (1986)

10. Bachtiar EW, Bachtiar BM, Soejoedono RD, Wibawan IW, Afdhal A: Biological and immunogenicity property of $\mathrm{IgY}$ Anti ComD. Open Dent J 10, 308-314 (2016)

11. Berkowitz BR: Etiology of nursing caries: A microbiologic perspective. J Public Health Dent 56, 51-54 (1996)

12. Roman C, Rivera A, Santellan R, Teutle B: Immunogenic antigens from Streptococcus mutans which stimulate secretory Iga response from parotid saliva in children with caries. World Appl Sci J 28, 297-303 (2013)

13. Russell RR, Peach SL, Colman G, Cohen B: Antibody responses to antigens of Streptococcus mutans in monkeys (Macaca fascicularis) immunized against dental caries. J Gen Microbiol [Internet] 129, 865-875 (1983)

14. Gómez SI, Jaramillo LM, Moreno GC, Roa NS, Rodríguez A: Differential of salivary IgA and IgG against Streptococcus mutans proteins in humans with different caries experience. Acta Odontol Latinoam 28, 3-12 (2015)

15. Paramita F, Annika P, Bachtiar EW, Yuniastuti M: Immunoglobulin-Y effect on protein of Streptococcus mutans isolated from caries and caries-free subject. Ina J Dent Res 17, 63-65 (2012)

16. Napimoga MH, Kamiya RU, Rosa RT, Rosa EA, Hofling JF, Mattos-Graner R, Gonçalves RB: Genotypic diversity and virulence traits of Streptococcus mutans in caries-free and caries active individuals. J Med Microbiol 53, 697-703 (2004)

17. Igarashi $\mathrm{T}$, Yamamoto $\mathrm{A}$, Goto $\mathrm{N}$ : Sequence analysis of the Streptococcus mutans Ingbritt dexA gene encoding extracellular dextranase. Microbiol Immunol 39, 853-860 (1995)

18. Sutcliffe IC, Hogg SD, Russell RR: Identification of Streptococcus mutans antigen D as the HPr component of the sugar-phosphostransferase transport system. FEMS Microbiol Lett 1, 67-70 (1993)

19. Harrington DJ, Russell RRB: Multiple changes in cell-wall antigens of isogenic mutants of Streptococcus mutans. J Bacteriol 175, 5925-5933 (1993)

20. Dao ML, Chavez C, Hirachi Y, Ferretti JJ: Molecular blotting of the Streptococcus mutans gene specifying antigen A. Infect Immun 57, 3372-3376 (1989)

21. Mattos-Graner RO, Porter KA, Smith DJ, Hosogi Y, Duncan MJ: Functional analysis of glucan binding protein B from Streptococcus mutans. J Bacteriol 188, 3813-3825 (2006)

22. Hazlett KRO, Michalek SM, Banas JA: Inactivation of the gbpA gene of Streptococcus mutans increases virulence and promotes in vivo accumulation of recombinations between the glucosyltransferase B and C genes. Infect Immun 66, 2180-2185 (1998)

23. Otsuka R, Imai S, Murata T, Nomura Y, Okamoto M, Tsumori H, Kakuta E, Hanada N, Momoi Y: Application of chimeric glucanase comprising mutanase and dextranase for prevention of dental biofilm formation. Microbiol Immunol 59, 28-36 (2015)

24. Hayacibara MF, Koo H, Smith AMV, Kopec KL, Schott-Anne K, Cury JA, Bowen WH: The influence of mutanase and dextranase on the production and structure of glucans synthesized by streptococcal glucosyltransferases. Carbohydr Res 339, 2127-2137 (2004)

25. Wiater A, Szczodrak J, Rogalski J: Hydrolysis of mutan and prevention of its formation in streptococcal films by fungal alpha-D-glucanases. Process Biochem 39, 1481-1489 (2004)

26. Szczodrak J: Mutanase induction in Trichoderma harizianum by cell wall of Laetiporus sulphureus and its application for mutans removal from oral biofilms. J Microbiol Biotechnol 18, 1335-1341 (2008) 